\title{
The urgency of testing standard for elderly's monitoring systems in Indonesia
}

\author{
Sunartoto Gunadi ${ }^{1}$, Zulkalnain bin Mohd Yussof ${ }^{2}$, Ahmad Yusairi bin Bani Hashim $^{3}$ \\ ${ }^{1}$ Surya University, Physical Energy Engineering,Tangerang15143, Banten, Indonesia \\ ${ }^{2}$ Fakulti Kejuruteraan Elektronik dan Kejuruteraan Komputer, Universiti Teknikal Malaysia, Melaka \\ ${ }^{3}$ Fakulti Kejuruteraan Pembuatan, Universitas Teknikal Malaysia, Melaka
}

\begin{abstract}
Due to several aspects, such as safety, applicability, and reliability of the elderly monitoring systems, it is urgently need a testing standard for this system. Commonly, the user, especially caregivers or nurse, do not know exactly that procedure. In order to educate both, consumer and producer, preventing problems which may arise among them, and guarantee that instrument is operate as well as stated on the instruction manual, which conform to a certain testing standard which introduced by legal institution (SNI or ISO), establishment a testing (physical and/or written) for this device, especially in Indonesia, is urgently needed.
\end{abstract}

Keywords: testing standard, monitoring systems

\section{Introduction}

In table 1 belows, USA have elderly people about $15.2 \%$ from their population, but for Japan, the number of Japanese people with ages 65 years or older nearly quadrupled in the last forty years, to 33 million in 2014, accounting for $26.3 \%$ of Japan's population.

Table 1. Percentage elderly population in several country [1]

\begin{tabular}{|c|l|c|c|c|}
\hline NO & COUNTRY & ELDERLY.S & YEAR & NOTE \\
\hline 1. & JAPAN & 33.9 Million & 2017 & $26.3 \%$ \\
\hline 2. & SWEDEN & 1.97 Million & 2017 & $19.8 \%$ \\
\hline 3. & UK & 11.8 Million & 2016 & $17.8 \%$ \\
\hline 4. & USA & 49.2 Million & 2016 & $15.2 \%$ \\
\hline 5. & INDONESIA & 21.5 Million & 2017 & $9.43 \%$ \\
\hline
\end{tabular}

Based on statistical data which released by Bureau of Communication and Society Care Ministry of Health, the population of the elderly in Indonesia are more than $9 \%$ from total population[1], especially in 3 province, ie Yogyakarta, Middle Java and East Java. It means, according to the definition, Indonesia already belong to ageing country [more than 8 $\%$. It has to a consequence for the government for introducing more reliable health services.

As stated by Prof. Dr. dr Siti Setiati, SpPD-KGer, Pergemi (Persatuan Gerontologi Medik Indonesia), in paper "Masalah Kesehatan yang Harus diwaspadai oleh Lansia"[2], that there are about $23 \%$ global problem health which belong to Elderly [Lansia] health. It 
was underlined by Laurie Orlov[3], that for the Elderly, mostly they have at least one of 14

I. In this paper, 14 ( fourteen I) are consists of:

1. immobility,

2. instability,

3. incontinence,

4. intellectual impairment,

5. infection,

6. impairment of vision and hearing, taste, smell, communication, convalescence,

7. integrity,

8. impaction,

9. isolation,

10. inanition,

11. impecunity,

12. iatrogenesis,

13. insomnia,

14. immune deficiency.

Another paper, written by Andrew Carle, executive-in-residence at the Program in Senior Housing Administration at George Mason University, stated that: falls "are also the number one cause of hospitalization due to injury for this age group." That is why, that "Emergency Response Technology especially, elderly monitoring systems, are important, because falls are the number one cause of death due to injury" in people over age 75 . In detail, the problem and solutiona is written in paper which topic "Fall Prevention for Older Adults" [4].

\section{Recent Condition}

Mobility [for people, especially elderly] is represented in the International Classification of Functioning Disability and Health (ICF) by classifier d460 - Moving around in different locations, [see Figure 1], that can be subdivided into:

- d4600 - Moving inside the house;

- d4601 - Move inside buildings than own home;

- d4602 - Move out of your home and other buildings

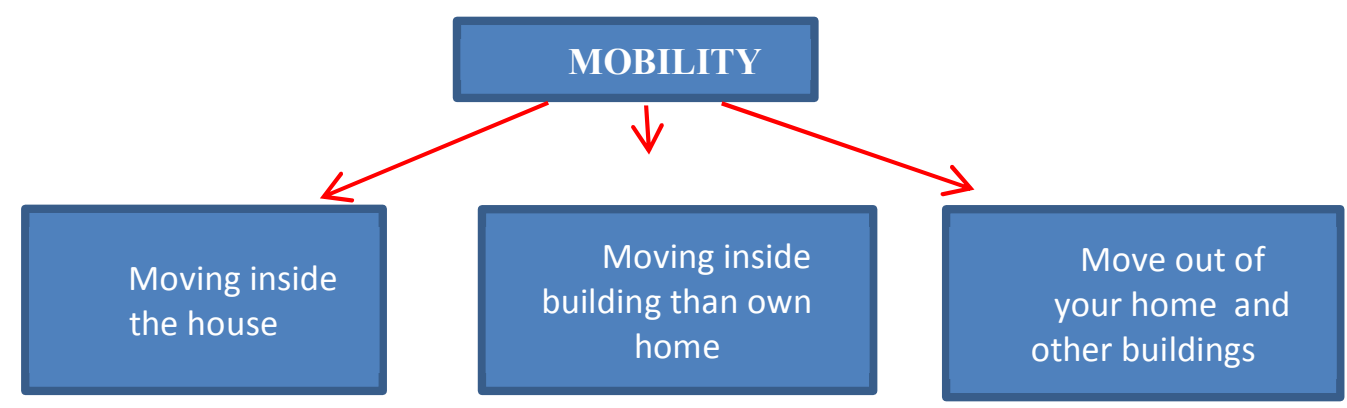

Figure 1. Mobility by ICF

Kirsten K. B. Peetoom and team on their paper "Literature review on monitoring technologies and their outcomes in independently living elderly people" [2], stated that there are 5 main groups of monitoring technology, ie:

1. in-home passive infrared motion sensors,

2. body-worn sensors,

3. video monitoring, 
4. pressure sensors, and

5. sound recognition.

As every monitoring system have to have an advantages and disadvantages, so using those monitoring systems, it should combine with the type of activity daily living and the mobility of the elderly, which may they choose moving inside the house, or may they move inside buildings than own home or they may move out of your home and other buildings.

\section{Problem and discussion}

\subsection{Problem}

In Indonesia, even only $9.43 \%$ the elderly population, but the number mostly 30 million already. In several province, especially in Java, recently, there are a lot of new Private Elderly house, were use some monitoring system. At east Java, a lot of private elderly houses use same monitoring device for their daily activities.

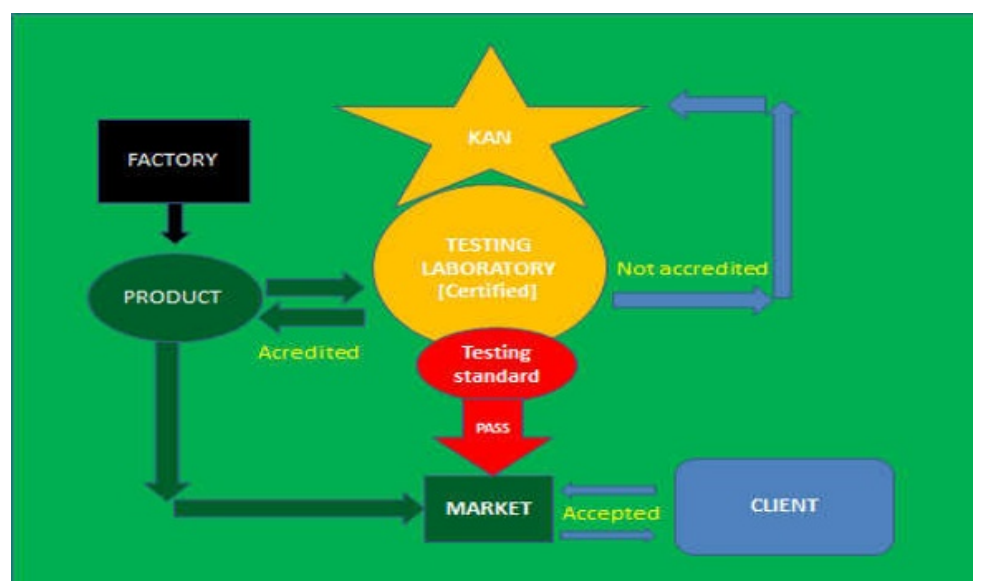

Figure 2. The role of Testing Standard

Due to the problem which may arise, cause by the technical specification of the monitoring system which are not conform to the user applicability or may be the reliability of the system which mismatch with reality, so the problem should be solve by the third party. But, in this case, if the testing standard [SNI or ISO] are available, solution of the problem will be solved easier.

\subsection{Discussion}

In Indonesia, recently already have about 198 acredited Calibration laboratory and 1043 Test Laboratory [11], unfortunately there is no laboratory which have competence in testing of such kind monitoring system. Relying on transition policy of KAN about ISO/IEC 17025:2017 and considering that Indonesia have to have a testing Laboratory which have competency in such monitoring systems, there are several alternative for overcoming the above problem:

a. The government hand in hand with the private company establish a New Testing Laboratory,

b. To improve established Testing Laboratory, such as LP Electromedic BPFK,

c. The Minister of Research and Technology, appointed Institute of Sciences, in order to developes the competency of both, Research Center for Metrology [P2M] 
and Research Center for Quality System and Testing Technology, in overcoming the problem which arise till 2020.

\section{Conclusion}

From this paper, simply we take a conclusion that:

1. Even recently already start, but anticipating elderly boomer on the next year 2020, it will arise and developed, a new business activity which closed related with elderly people, ie Private Elderly house.

2. As consequences of this Private Elderly house, there are a new demand of equipment which closely related with Elderly daily activity, such as Elderly Monitoring System.

3. To prevent conflict arise about such system which do not perform as the consumer need, earlier Testing Laboratory, which have standard of conformance in testing competency (both, physical and written) is established as earlier as possible.

\section{References}

1. World Population Ageing - the United Nations; (2017) www.un.org/en/development/desa/population/.../pdf/ageing/WPA2015_Report.pdf

2. S. Setiati, SpPD-KGer, On "Masalah Kesehatan yang Harus diwaspadai oleh Lansia" Pergemi (Persatuan Gerontologi Medik Indonesia), (2016).

3. K K. B. Peetom 1,2, M A. S. L1, M Joore3, C D. Dirksen 3and L. P. De Witte1,21 On Literature review on monitoring technologies and their outcomes in independently living elderly people; Research Centre for Technology in Care, Zuyd University of Applied Sciences, Heerlen, the Netherlands, (2015).

4. "Fall Prevention for Older Adults"; The American Occupational Therapy Association. Inc, (2012).

5. M.R. Marques ${ }^{1}$; T.M. Raymundo ${ }^{2}$; C.S. Santana ${ }^{3}{ }^{1}$ Master student at Post Graduate Program Interunits Bioengineering EESC/FMRP/IQSC -University of Sao Paulo, Brazil, On Use of sensors systems to monitor the mobility of elderly; Journal of Physics: Conference Series, Volume 477, conference 1 (2013)

6. K. Guan, M. Shao, and S. Wucor; On A Remote Health Monitoring System for the Elderly Based on Smart Home Gateway, (2017).

7. Pedoman Pengembangan Standar Nasional Indonesia; PSN 01, (2007).

8. Population Reference Bureau; Fact Sheet: Aging in the United States, (2016).

9. Office for National Statistics; Overview of the UK population: July 2017, (2017).

10. Aging of Japan; https://en.wikipedia.org/wiki/Aging_of_Japan

11. Kan.or.id - (2018) 